\title{
Technological Solution for Rural Sanitation Structures
}

\author{
Mr. A. D. Patil ${ }^{1}$, Mr. Mandar Bankar ${ }^{2}$, Mr. Sourabh Londhe ${ }^{3}$, Mr. Sagar Birajdar ${ }^{4}$, \\ Mr. Pradip Pawar ${ }^{5}$, Mr. Niraj Hajare ${ }^{6}$ \\ ${ }^{1}$ Assistant Professor, Civil Engineering Department, ADCET, Ashta, India. \\ 2,3,4,5,6 Student, Civil Engineering Department, ADCET, Ashta, India.
}

\begin{abstract}
This paper comprises some research features related to sanitation. Potential champions for improving sanitation can be found in every community, as can people with the necessary building and organizational skills. Family members and the local private sector are often the primary designers and providers of sanitation services. These activities contribute to the improvement of the livelihoods in a community. Sanitary officials and public health workers play an important role in facilitating private entrepreneurs and the creating awareness about the importance of proper hygiene and sanitation. It is a major challenge to "halve by 2015 the proportion of people without sustainable access to safe drinking water and basic sanitation". Only through a considerable increase in the construction and improvement of sanitation facilities within the next ten years, can the sanitation target be achieved.
\end{abstract}

Keywords-Sanitation; organisation; toilet

\section{INTRODUCTION}

The two most commonly used sanitation technologies today are the pit toilet and the flush toilet. Conventional waterborne sewage have proven to be inappropriate to solve sanitation needs in developing countries. The systems are too costly to provide to all, and only wealthier upper and middle class areas are normally provided with those services. Approximately $90 \%$ of the sewage in cities in developing countries is today discharged untreated, polluting rivers, lakes and coastal areas. Pit toilets also have limitations, especially in densely populated areas, with severe risks of contaminating groundwater.

Within 20 years from insecurity, decreasing soil fertility and escalating prices for fertilizers in world markets, there is a need to utilize the nutrients, especially in human urine, rich in nitrogen and phosphates, for agricultural purpose, thereby increasing productivity and needs for fertilizers. It is obvious that enormous challenge leads to a rethink, a need to raise the status of sanitation and a need for new approaches, techniques and methods.

\section{PROBLEM DEFINITION:}

The Present Scenario Is 30\% Of Villages In Maharashtra Are Without Toilets Having The Entire Problem Listed Above. Even Though There Is A Continuous Effort Toward Rural Sanitation Either It Is Viewed Secondary Or A Neglected Aspect Of Life Without Really Knowing THE Effect Of Such A Sanitation System.

Therefore, There Is A Need That Alternative And Appropriate Methods Of Designing The Rural Sanitation Systems, Like Sustainable Methods Construction Of Rural Toilets, Use Of Alternative Materials, Economy Etc.

In This Context Two Villages Namely Beldarwadi In Walwa Taluka Of Sangli District Have Been Selected For
Field Survey And Asses Water Quality Parameters. Further, As A Value Added Product Vermi-Compost Of Cow Dung Are Subjected To Urine Treatment And Sludge Of Two Pit Latrines.

Rational:

With The Increase Of Growing Rural Population In The Villages In Concern, The Un Systematic Way Of Disposal Of Liquid And Solid Wastes Generated Has Led To The Poor Sanitation Conditions Prevailing, Leading To Serious Environmental Degradation And Affect On The Health Of People, Especially The Health Of Women Is Being A Serious Threat Even Though She Is The One Bringing The Growth Of The Whole Family. Therefore The Swachh Bharath Mission Of Government Of India Addresses Timely Both Rural And Urban Sanitations. The Mission Aims At Achieve A Swachh Bharat by 2019, As A Fitting Tribute To Mahatma Gandhi On His 150th Birth Anniversary.

Further With The Increase In The Cost Of Chemical Fertilizers And There Non Availability Of Sufficient Quantity And There Toxic Effects On The Land Ecosystem The Production Of Alternative Organic Manure And Harvesting Urine Energy Is Being Considered As Simple And Economically Viable Solution.

Objectives:

$>$ To Identify Demerits Of The Existing Sanitation Structure.

$>$ To Design Environmental Friendly And Sustainable Rural Toilet.

$>$ To Analyze Nutrient Content Of By -Products Of Sanitation Waste.

$>$ To Suggest The Economical Model By Using By Product Of Sanitation Waste.

$>$ To Design The Fertilizer From Waste.

$>$ Maintences and Overall Development Of Sanitation Structures.

$>$ To Give An Innovative Solution For Usage And Operation.

Scope of Study:

$>$ Field Study Of Villages And Collection Of Water Samples

$>$ Laboratory Study Of Water Samples

$>$ Laboratory Study Of Vermi-Compost Treated With Urine For Energy Values

$>$ Laboratory Study Of Bioconversion Of Two Pit Latrine Sludge And Energy Values

$>$ Designing Of Urine and Human Feaces Separating Toilet. 


\section{LITERATURE REVIEW}

Human Feaces Are Generally Fertilized By The Simple Method Of Vermicomposting. One Of The Earthworm Species "Eisenia Fetid" Is Not Able To Survives When It Introduce With Fresh Human Feaces,So Modification In Physical Characteristics Of Feaces Was Necessary Before Earthworms Could Be Introduced To Feaces. . A Preliminary Study With Six Different Combinations Of Feaces, Soil And Bulking Material (Vermicompost) In Different Layers Was Conducted To Find Out The Best Condition For Biomass Growth And Reproduction

Earthworms. The Results Indicated. A Preliminary Study With Six Different Combinations Of Faeces, Soil And Bulking Material (Vermicompost) In Different Layers Was Conducted To Find Out The Best Condition For Biomass Growth And Reproduction Of Earthworms. The Result Will Be Found That Was, The Combination Of SVFV [Soil, Vermicomosting, Feaces, And Vermicomposting Biomass Growth Indicating The Positive Role Of Soil Layer In Earthworm Biomass Growth. However It Seems Looks , The Soil Layer Will Not Much Enhance Vermicomposting Composting Rate.Yer Long Year Ago Only Study With VFV[Vermicomposting] Feaces Vermicomposting Assess The Average Of Quality And Quantity Of Vermicompost Produced With An Vermicompost Production Rate Of 0.30 $\mathrm{Kg}$-Cast/Kg-Worm/Day.

The Vermicomposting Was Achieved By Mature Low Dissolved Organic Carbon $(2.4 \pm 0.43 \mathrm{Mg} / \mathrm{G})$ And Low Oxygen Uptake Rate $(0.15 \pm 0.09 \mathrm{Mg}$ O2/G VS/H). Complete Inactivation Of Total Colliform Was Noted During Studies. This Was The Most Important Objective In Human Feaces Processing.

\section{Hygienic Quality Of Faeces Treated In Urine Diverting Vermicomposting Toilets}

In Recent Of Years On Site Sanitation Solutions Gets More And More Interest .One Such New And Innovative Idea Is "Urine Diverting Vermicomposting Toilets" [UDVT].This Study Was Evaluated The Hygienic Quality Of The Composted MATERIAL IN SIX UDVT, S IN FRANCE.

The Vermicomposting Technology Has Been Explored On A Wide Variety Of Organic Wastes, Including Sewage Sludge, Municipal

Waste, Pig And Cow Manure And Human Excrement Demonstrated The Feasibility Of Using The Vermicomposting Technology As Treatment Of Source Separated Faeces. In His Thesis He Developed A Continuous Single Chamber Vermicomposting Toilet. He Found That Optimal Conditions for Vermicomposting of Faeces Was at a Moisture Content Of $65-80 \%$ At 20-25 _C, Achieving 50-80\%Reduction In Organic Carbon After 96 Days Of Treatment.

The Main Question with Udvts Is Whether The Processed Material, Aside From Being Stabilized, Also Can Be Considered Hygienically

Safe. Numerous Reports Demonstrate the Capacity Of Vermicomposting Systems To Inactivate Enterobacteriaceae, Such

As Salmonella Spp., Escherichia Coli And Shigella Spp. (Contreras-Ramoset Al., 2005; Monroy Et Al., 2009; Kumar And Sweat, 2011).However, Opinions Differ
Whether Vermicomposting Has The Abilitydestroy Or Inactivate Parasites Such As The Intestinal Worm Ascarisspp. (Eastman Et Al., 2001; Bowman Et Al., 2006; Hill Et Al., 2013), While Little Is Known About Its Effect On Viruses.

In This Study, The Hygienic Quality Of Human Waste Treated Inudvts - Employing Epigeic Earthworm Eisenia Foetida - That Had Been In Operation Between Two And Five Years, Was Investigated.Concentrations Of Salmonella Spp., Enterococcus Spp., Thermotolarent Coli Forms And Naturally Occurring Coliphages (Used As Indicatorfor Animal Viruses), As Well As Physic-Chemical Parameters,Analysed.

Vermicompost Production Rate Was Found Varying In The Range $0.23-0.35 \mathrm{Kg}$-Cast/Kg-Worm/Day With An Average Value Of0.30 Kg-Cast/Kg-Worm/Day During The Study Vermicompostproduction Rate Generally Depends On The Characteristics Of Feed, Environmental Conditions And Type Of Earthworm Species. Gajalakshmiet Al. (2001), Jain Et Al. (2003) Reported, Vermicastproduction Of 0.20-0.29 And $0.20-0.21$ G-Cast/G-Worm/Dayrespectively.One Of The Important Advantages Of Vermicomposting Over Composting Is Its Ability To Destroy Pathogenic Organisms. In The Present, No Coli Forms Were Detected In Any Of The Maturevermicompost Samples Tested, While The Faeces Had An Average Coli Form Content Of 5.0 - 109 MPN/G. In Vermicomposting, Killing Of Pathogens Is Prominently Achieved Through Earthworm Actions Such As Intestinal Action, Secretion Of Fluids And Selective Grazing.

\section{Composting Toilets As A Sustainable Alternative To Urban Sanitation}

The Current Water Infrastructure In Developed Countries Requires Lot Of Energy And Produces Quality Of Potable Water For All Uses, Such As Drinking, Irrigation, And Toilet Flushing. In The U.S., the Water and Wastewater Treatment

Systems Use Approximately3\% Of Total U.S. Electricity. Using Energy Intensive Processes To Produce Water And Then Using This High Quality Water For Flushing Toilets Is Inefficient Management Of Both Water And Energy Resources. Composting Toilets Require Little To No Water And Can Therefore School (60\%). Composting Toilets Also Fit In With Today's Understanding of Sustainable Construction since They Reduce Water and Wastewaters Disconnect the Toilet from Both the Water Supply and Wastewater Infrastructure. Such Water And Wastewater Savings Can Be Significant At System Level Since Toilet Flushing Constitutes The Highest Percentage Of Water Use In Residential $(27 \%)$ Office $(51 \%)$, Flows Within A Building. In The U.S. The Most Common Green Building Rating System Is The U.S. Green Building Council's (USGBC).

Leadership In Energy And Environmental Design (LEED). Compostingtoilets Are Recognized By The USGBC And They Have Been Used To Achieve LEED Certifications. More Specifically, The Use Of Compostingtoilets In A New Construction Or Major Renovation Building Can Help Earn 
The Water Use Reduction And Innovative Wastewatertechnologiescredits Within The Water Efficiency (WE) Category Of From Traditional Wastewater treatment Plant, The Solids Obtained From Composting Toilets Can Also Be Used As A Fertilizer; Yet They Would Be Free From The Urban Runoff Contamination And May Require Less Transportation If They Can Be Applied Where Compost Is Produce.

Types of Sanitation Technologies

Sanitation Technologies Can Be Water Based or Composting

Based (Fig.). In Water Based Systems, the Flushed Water Source

Sanitation Systems:

1) Water Based:

(Potable, Rainwater, or Greywater Based)

A) Treatment Method:

(Municipal Wastewater, Septic Tanks,

Wetlands Or Living Machines)

2) Composting Based:

(Dry, Pint Flush, Foam Flush)

B) Treatment Meth (Composting)

Composting Based Sanitation Systems Are Known As Composting Toilets, Dry Toilets, Biological Toilets, BioToilets, Or Waterless Toilets. They Are Typically Made, Ceramic, Or Fibreglass. A Composting Toilet Has Two Primary Components; The Toilet And The Composting Tank. The Other Parts Of A Composting System Often Include A Fan And Vent Pipe To Remove Any Odour. There Is Typically A Drain To Remove Excess Leacheat And Access Doors To Empty Compost. Composting Systems Require Little Or No Use Of Water For Conveyance Of Wastes. Similar To The Conventional Toilet, The Toilet In A Composting System Is A Waste Collector. The Waste Is Collected Into The Composting Tank Where It Is Digested Aerobically. Some Systems May Use (Vermicomposting) As An Alternative To Aerobic Composting. Bulking Agents Or Amendments (E.G. Sawdust, Leaves, And Food Waste) Are Often Added To Help Co-Manage Different Types Of Waste, Adjust Carbon To Nitrogen Ratio, And Increase Porosity Of The Compost. Sawdust Is A Popular Amendment Because It Creates An Environment For Bacteria To Thrive With Its High Porosity, High Water And Air Retention And High Drainage Properties. In Addition, The Low Density Of Saw Dust $(0.19 \mathrm{G} / \mathrm{Cm} 3)$.

Human Urine As A Low Cost And Effective Nitrogen Fertilizer For Bean Production In The Whole World There Are Many Countries Uses Chemical Fertilizers In Overdose Which Attributes To Critical Environmental And Health Problems Such As Chronic Kidney Disease(CKD) In SriLanka Therefore May Researcher And Scientists Had Decided To Finding One Of The Low Cost Effective ,Fertilizers Substitutes For Inorganic Fertilizers In Crop Production Human Urine Is One Of The Best Component For Production Of Such Low-Cost Effective Fertilizers
Which Are Rich In Nutrients' Like Nitrogen,Phosphrous And Potassium .

This Research May Be Found When "Human Urine "Is Directs Used As Fertilizers In "Edible Crops" Production As Low Cost And Effective Nitrogen Fertilizers. The Study Of Urine Fertilizer May Be Conducted In A "Greenhouse "Using "Bushita Bean" As Crop Species.

Five Treatments May Be Made-

1) TEST 1 [Albert Solution]

2) TEST 2 [Agriculture Departments Recommendation For Nitrogen $\mathrm{N}$

Phosphorous P, Potassium K, Fertilizers Urea (TSP \&MOP)]

3) TEST 3 [Human Urine; Nitrogen Concentration Adjusted To 20\%

Less Than Nitrogen Concentration T2]

4) TEST 4 [Human Urine; Nitrogen Concentration Adjusted

Similar To T2]

5) TEST 5 [Human Urine; Nitrogen Concentration Adjusted

To 20\% More Than The Concentration In T2]

Were Applied For Three Weeks After Planting, After Results Taken Out ,T5 Results Showed Highest Leaf Area ,Root Dry Weight And Total Nitrogen Content Of Leaves. Bean Yields Was Significantly Higher $(\mathrm{P}<0.05)$ In Plants Received T1\&T2.Compared To Urine -Fertilized Treatments Even Though Bean Yields

\section{KEY POINTS OF RESEARCH}

In Our Project, We Prepares A Toilet Model Which Included Innovative Idea About Current Toilet Technology. In Our Toilet Model, We Prepares A System Which Diverges The Urine Like Other Matter And Human Waste (Human Feaces) Like Solid Matter. Due To Which We Get Valuable "Urine" For Production Of Urine Fertilizer Which Is Very Very Rarely Used In Asia.

The Material We Are Using For Toilet Could Be Economical, Environment Friendly, Easily And Locally Available Material.

This Separation Can Be Converted Into Usable And Nutrient Filled Fertilizer Which Is Convenient For Use Of People In Their Farms And Other Related Use Also.

The Side Walls Which Supports Toilet Roof Are Also Made From Innovative And Low Cost ,Effective Material Name As "PLASIPLY" \{Combination Of Plastic+ Plywood Dust $\}$ Which Has Properties Of Easy To Handle,Excellent Thermal Insulation,Easy And Safe To Handle,Excellent Performance And Stability,Environment Friendly and User Friendly.

Also PLASTPLY Is Very Cheaper Material Than Comparative To Othere Material Available In Market For Construction Of Wall.

However Usually The Cost Of Normal And Simple Conventional Toilets Total Construction Cost Goes Up to 20 Thpousand To 22 Thousand. But According To Our Designed Innovative Toilets Total Completion Cost Goes Up to 13thouasnd Only Which Was Very Feasible To Every Person In Village Also It Is Useful For DIFFERENT GOVERNMENT SCHEMES Also. 


\section{REFERENCES}

[1] "Conceptual Energy and Water Recovery System for Self-Sustained Nano Membrane Toilet" by Dawid P. Hanak et al. at Elsevier Energy Conversion and Management 126 (2016) 352-361, 12 August 2016.

[2] "The toilet tripod: Understanding successful sanitation in rural India” by Kathleen O'Reilly, Elizabeth Louis at Elsevier - Health \&Place 29(2014)43-51

[3] "A Mechanical Automatic Urinal-Toilet Flusher for Swach Bharat Mission" by S.B. Wath et al. at International Conference on Solid Waste Management, 5Icon SWM 2015, Elsevier - Environmental Sciences 35 (2016) 185 - 192.

[4] "Sustainability of Community-Led Total Sanitation Outcomes: Evidence From Ethiopia And Ghana" by Jonny Crocker et al. at Elsevier - International Journal of Hygiene and Environmental Health 220 (2017) 551-557.

[5] "Sustainable Disposal of Domestic Sanitary Waste" by Richard Ashley from Journal of Environmental Engineering, ASCE, February 2005 131(2) Page No. 206-215.

[6] "Urine-Diverting System for Securing Sanitation in Disaster and Emergency Situations" by Hidenori Harada et al; from Leadership and Management in Engineering October 2012 12(4): Page No. 309-314.

[7] "Optimization Techniques For Secondary Wastewater Treatment System" by Chi-Chung Tang et al; Journal of Environmental Engineering, Vol. 113, No. 5, October, 1987. ASCE, ISSN 07339372/87/. Paper No. 21840. 113(5): Page No.935-951.

[8] "Comprehensive Model Of Activated Sludge Wastewater Treatment System" by Chi-Chung Tang et al; Journal of Environmental Engineering, Vol. 113, No. 5, October, 1987. ASCE, ISSN 0733-9372/87/0005-0952/\$01.00. Paper No. 21841. 113(5): Page No. 952-969

[9] Booklet of Asian Development Bank, "Water for All" Series 18: India's Sanitation for All: How to make it happen

[10] Smart Sanitation Solutions, Booklet published at 4th World Water Forum held at Mexico in 2006. 